\title{
土木学会論文報告集
}

第 169 号・1969 年 9 月

\section{塔状構造物の固有周期の自乗和を最小ならしめる 断面変化に関する三，三の考察 \\ DESIGN OF A CANTILEVER BEAM SECTION UNDER MINIMIZING THE SQUARE SUM OF NATURAL PERIODES}

\author{
中 川 建 治* \\ By Kenji Nakagawa
}

要 旨 構造部材の総体積を一定量に保ちつつ, 塔 状構造物, あるいは, 高層ラーメンの固有周期の自乗和 を最小にするような設計法を導いた。塔やラーメンの高 さは任意である。

このような設計法は, それぞれの固有周期に近い周波 数成分のみより成るパワースペクトルをほぼ等しい大 きさで含むランダム外力に対する応答の運動エネルギー の平均を最小化する設計法で, 剛な構造物の設計方法で ある。

\section{1. まえがき}

本文で論ずる塔状構造物の固有周期 $T_{i}(i=1,2, \cdots)$ の 自乗和 $\Gamma=\Sigma T_{i}{ }^{2}$ を最小にする断面変化の決定法は, 外 力に対する応答と許容応力度に基づく従来の構造物の設 計方法に比較すれば, 特異な考え方であって, 構造物の 設計にただちに役立つものとは思われない。なぜなら ば，この設計法は，片持ばりのような塔状構造物や高層 ラーメンにおいて，高さをあらかじめ決めておき，一定 量の構造材料を用いて，許容応力度とは関係なく $\Gamma$ を 最小にするような断面設計を目的としたものである。片 持ばりでは， $\Gamma$ (以下において，固有周期の自乘和を $\Gamma$ と略記する）の中における基本周期 $T_{1}$ の占める比率が 大きいので， $\Gamma$ を小さくすることは，近似的に $T_{1}$ を小 さくすることになる。したがって，なんらかの必要性か ら, 基本周期を小さくして最も剛な構造物（たとえば高 さの大きな橋脚）を設計しょうとする場合には，本文に 示した 2,3 の結果は参考になるものと思う。はりの断 面変化と固有值の逆数和の変化の関係については, 著者 がすでに文献 1）で報告したが，引き続き本文を報告す るのは，特殊な構造物設計においては，本文のような考 え方もなんらかの参考資料になるのではなかろうかと思

* 正会員 工修 山口大学助教授 工学部土木工学教室
うからである。

構造物を有限 $N$ 自由度の構造物とみなして, Flexibility matrix を $F=\left[f_{i j}\right]$, 各格点の集中質量を $m_{j}$ と すれば，固有周期の自乗和は，

$$
\Gamma=\sum_{j=1}^{N} T_{j}{ }^{2}=4 \pi^{2} \sum_{j=1}^{N} m_{j} f_{j j}
$$

として与えられる。構造物を無限自由度系の連続体とみ なして, 単位荷重による載荷方向たわみを $w(x)$, 単位 長さ当りの質量を $\rho(x)$ とすれば,

$$
\Gamma=4 \pi^{2} \int \rho(x) w(x) d x
$$

となる (文献 1) 参照)。積分は構造物全体にわたり， すべての自由度方向に行なう。

高層ラーメンと塔状構造物を対象にして, 構成材料の 総体積を一定に保ちながら $\Gamma$ を最小にする断面変化を 示し, 最後に $\Gamma$ をいかに解釈し得るか, パワースペク トルとの関連はどのようになるかなどを示す。

\section{2. 高層ラーメン}

図一1 に示すような高層ラーメンにおいて, 柱の部分 の総体積 $V$ を一定に保ちつつ $\Gamma$ を最小にするような 柱の断面を決定し よう。ラーメンに 対してつぎのよう な仮定を設ける が, 一般の建築物 に対する仮定とし ても, 十分許容し 得るものであろ 引。

（1）各層の床 部分の質量は既知 であるとして, 柱

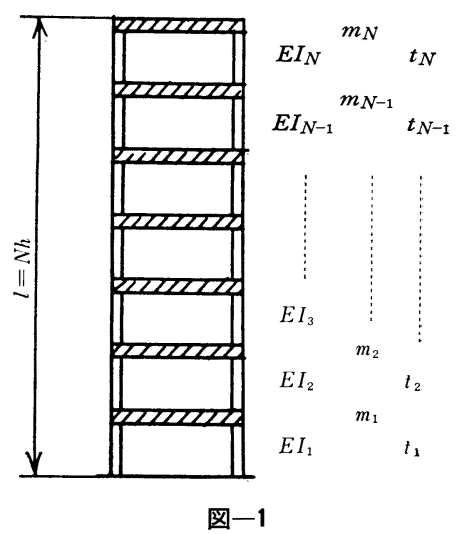


部分の質量も各床部分へ集中させる。したがって床部分 の質量を $m_{1}, m_{2}, \cdots \cdots, m_{N}$ として，柱の質量を 0 とす る。

（2）各層間の柱の断面はそれぞれ等断面であって， 各層間で階段状に変化している。

（3）各層の相対変位は柱の曲げ変形によってのみ生 ずるものとして, 各層の回転振動は無視する。柱の曲げ 剛さを $E I_{j}(j=1,2 \cdots N)$ とする。せん断変形の場合に ついては後述する。

（4）各層の高さを $h_{j}$, 柱部分の総体積を $V$ とする。

さて, 柱の断面を表わす变数を $t_{i}$ とすると, 各層の 相対変位を与える断面曲げ剛さと柱の部分の総体積 $V$ は,

$$
\begin{aligned}
& E I_{j}=\beta_{j} t_{j}{ }^{\zeta} \quad(\zeta \geqq 2) \\
& V=\sum_{1}^{N} r_{j} h_{j} t_{j}{ }^{\theta} .
\end{aligned}
$$

となる。ここに, パラメーター $\beta_{j}, \gamma_{j}, \zeta, \theta$ は柱の断 面形状 (円形, あるいは, 長方形) と各層に含まれる柱 の本数などによって決定するものである。

単位の水平力によって各層に現われる相対変位を $\Delta_{k}$ とすれば, パラメーター $\delta_{k}$ と $\Delta_{k}$ の関係は $\Delta_{k}=\delta_{k} / \beta_{k} t_{k}{ }^{\zeta}$ として表わされる。これらの值より $\Gamma$ を求めて， $\Gamma$ を 最小にするような $t_{k}$ を決定すればよい。式 (1.1) にお ける $f_{i i}$ は $f_{j j}=\sum_{1}^{j} \Delta k$ であるから, $\Gamma$ はつぎのように なる。

$$
\begin{aligned}
& \Gamma=4 \pi^{2} \sum_{1}^{N} \frac{\delta_{j} \alpha(j)}{\beta_{j} t_{j}^{\zeta}} \\
& \alpha(j)=\sum_{k=j}^{N} m_{k}
\end{aligned}
$$

ここで，拘束条件式 $(2.2)$ のもとに $\Gamma$ を最小にするよ うな $t_{j}$ を求めるにはパラメーター $\varepsilon$ を用いて Lagrange の未定係数法を用いればよい。結果を式 (2.3), 式 (2.4) に示す。

$$
\begin{aligned}
& g=\sum_{1}^{N} \gamma_{j} h_{j} t_{j}^{\theta}-V=0 \\
& \frac{\partial}{\partial t_{j}}(\Gamma+\varepsilon g)=-\frac{4 \pi^{2} \zeta \delta_{j} \alpha(j)}{\beta_{j} t_{j}^{\zeta+1}}+\theta r_{j} h_{j} t_{j}^{\theta-1} \varepsilon=0 \\
& \therefore t_{j}=\left\{\alpha^{\prime}(j)\right\}^{1 / \zeta+\theta} \cdot C^{\prime} \\
& \alpha^{\prime}(j)=\frac{\delta_{j}}{\beta_{j} r_{j} h_{j}} \sum_{k=j}^{N} m_{k} \\
& \left.C^{\prime}=V^{1 / \theta}\left[\sum_{k=1}^{N} r_{k} h_{k}\left\{\alpha^{\prime}(k)\right\}^{\theta /(\zeta+\theta)}\right]^{-1 / \theta}\right]^{\cdots(2.3)} \\
& \Gamma=4 \pi^{2} V^{-\zeta / \theta}\left[\sum_{k=1}^{N} r_{k} h_{k}\left\{\frac{\delta_{k} \alpha(k)}{h_{k} \beta_{k} r_{k}}\right\}^{\theta /(\theta+\zeta)}\right]^{(\theta+\zeta) / \theta}
\end{aligned}
$$

ラーメンにおける水平変位は, 曲げ変形以外にせん断 変形による場合もある。せん断変形の影響を考虑する場 合には, パラメーター $\beta_{k}, \delta_{k}, \zeta$ を適当に定めることに よって上記の結果をそのまま適用し得ることは明らかで
ある。なお，図一1 では 1 スパン ラーメンを仮定した が，柱の数には制限はないので，高層多スパン ラーメ ンでも適用可能である。

式 (2.3) より実際の断面形状 $t_{j}$ を求めるには, 絽り 返し計算によらなければならない。簡単に計算順序を示 す。

（1）設計条件より総体積 $V$ ，その他のパラメーター $\beta_{j} \gamma_{j}, \zeta, \theta$ を決定する。

(2) 断面形状 $t_{j 0}$ を仮定する。

(3) パラメーター $\delta_{k}$ を計算する。

（4）自重にもとづく $m_{k}$ を計算し， $\alpha^{\prime}(j)$ を決定す る。

（5）式 (2.3) にこれらの結果を代入して $t_{j}$ を求め る。

（6）収れん誤差 $\varepsilon$ に対して $\left|t_{j 0}-t_{j}\right| \leqq \varepsilon$ を満足し ない場合は, $t_{j} \rightarrow t_{j 0}$ として (2) 一戻って計算 を繰り返す。

(1) （6）に捣て $k, j$ は, $k, j=1,2 \cdots N$ 全体に わたって条件を満足するものとする。

この繰り返し計算の収れん性はきわめて良好である。 計算例を後述する。

\section{3. 有限自由度系としての塔の曲げ振動}

煙突のように曲げ変形に基つく横振動を起こす構造物 を有限自由度系とみなして解析する場合，曲げ剛さの配 分をいかにしたら $\Gamma$ を最小になし得るであるらか。

構造物を 図一2 に示すようなもの と仮定する。

(1) 高さを $N$ 等分して分割点へ 質量を集中させ る。集中質量 $m_{i}$ は既知とする。

(2) 曲げ剛さ $E I_{i}$ は各区間で一 定で, 階段状に変 化している。区間 の長さを $h$ とす

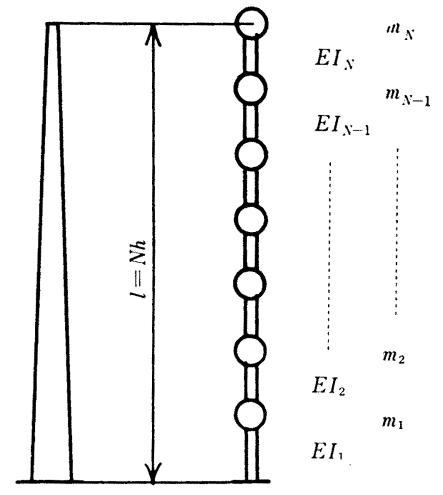

図-2 る。

（3）曲げ変形による横振動のみを考えて, 回転振動 は無視する。

さて, 式 (1.1) における $f_{k k}$ は, 単位荷重の載荷点 載荷方向のたわみであるから，

$$
f_{k k}=\int_{0}^{k h} \frac{(k h-x)^{2}}{E I(x)} d x
$$




$$
\begin{aligned}
= & \sum_{j=1}^{k} \frac{h^{3}}{E I_{j}}\left[k^{2}-\left\{j^{2}-(j-1)^{2}\right\} k\right. \\
& \left.+\frac{1}{3}\left\{j^{3}-(j-1)^{3}\right\}\right]
\end{aligned}
$$

となる。断面形状を表わす変数を $t_{k}$ として，パラメー ターを $\beta_{j}, \gamma_{j}, \zeta, \theta$ とすれば, 断面の曲げ剛さと総体 積 $V$ は,

$$
\begin{aligned}
& E I_{j}=\beta_{j} t_{j}{ }^{\zeta} \\
& V=h \sum_{j=1}^{N} \gamma_{j} t_{j}{ }^{\theta} .
\end{aligned}
$$

となる。前節と全く同様にして， Lagrange の未定係数 法によって， $\Gamma$ を最小にする $t_{j}$ が得られる。拘束条件 式 (3.1) のもとに,

$$
\begin{aligned}
\Gamma=h^{3} \sum_{1}^{N} \frac{1}{\beta_{j} t_{j}{ }^{\zeta}} \alpha(j) & \\
\alpha(j)= & \sum_{k=j}^{N} k^{2} m_{k}-(2 j-1) \sum_{k=j}^{N} k m_{k} \\
& +\frac{1}{3}\left(3 j^{2}-3 j+1\right) \sum_{k=j}^{N} m_{k}
\end{aligned}
$$

を最小にする結果のみを示すと，つぎのようになる。

$$
\begin{aligned}
t_{j} & =\left\{\frac{\alpha(j)}{\beta_{j} \gamma_{j}}\right\}^{1 /(\zeta+\theta)} \\
& \times\left[\frac{V}{h \sum_{k=1}^{N} \gamma_{k}\left\{\frac{\alpha(k)}{\beta_{k} \gamma_{k}}\right\}^{\theta /(\theta+\zeta)}}\right]^{1 / \theta} \cdots \cdots \cdots \cdots(3.2) \\
\Gamma & =4 \pi^{2} h^{3+\zeta / \theta} V^{-\zeta / \theta}\left[\sum_{k=1}^{N} \gamma_{k}\left\{\frac{\alpha(k)}{\beta_{k} \gamma_{k}}\right\}^{\theta /(\theta+\zeta)}\right]^{(\theta+\zeta) / \theta}
\end{aligned}
$$

これらは前節の結果と同じ形式のものであることがわ かる。実際の $t_{j}$ を求めるには繰り返し計算によらなけ ればならないが，前節に述べた計算法をそのまま適用す ればよい。

\section{4. 無限自由度系の曲げ振動}

有限自由度系における Lagrange の未定係数法による 解法は, 連続体 (無限自由度系) における変分法に相当 するものであって，連続体において も，前節と同様な関係式によって， $\Gamma$ 最小の断面 (以下において $\Gamma$ 最小の 断面を最適断面と仮称する）が決定 される。

図一3 に示すような変断面ばりにつ いて最適断面を求めよう。単位長さあ たりの質量を $\rho(x)$ として, 曲げ剛さ を $E I(x)$ とする。 $A(x)$ を断面積と して, $\rho_{0}$ を単位体積質量とする。

$$
\left.\begin{array}{l}
\rho(x)=\rho_{0} A(x) \\
E I=E I(x)
\end{array}\right\}
$$

単位荷重による載荷点載荷方向たわ
み $w(x)$ を水平方向たわみのみにするならば， $\Gamma$ はつ ぎのようになる。

$$
\left.\begin{array}{rl}
\Gamma & =\frac{\rho_{0}}{E} \int_{0}^{l} A(x) \int_{0}^{x} \frac{(x-z)^{2}}{I(z)} d z d x \\
& =\frac{\rho_{0}}{E} \int_{0}^{l} \frac{\alpha(z)}{I(z)} d z \\
\alpha(z) & =\int_{z}^{l} A(x)(x-z)^{2} d x
\end{array}\right\}
$$

変断面ばりでは， $I(x)$ が末知関数である限り $A(x)$ も未知関数である。したがって, 式 (4.2) における $\alpha(x)$ も $I(x)$ も同時に末知関数である。この難点を解決する ために, $I(x)$ の変化より $A(x)$ の変化がゆるやかであ ることに着目して, $A(x)$ を既知関数と仮定しよう。こ の仮定は，高層ラーメンの各層の質量は柱の曲げ剛性と は独立に既知であると仮定することに相当する。あるい は，つぎのように解釈してもよい。煙突のような構造物 において, 曲げ剛さとして有効な部材の断面積を $A_{1}(x)$ として，ライニングなどのように曲げに抵抗しない部材 の断面積を $A_{0}(x)$ とするならば, $A_{0}(x)$ は既知であっ て $A_{1}(x)$ は末知であるが, $\rho_{0} A(x)=\rho_{0} A_{0}(x)+\rho_{1} A_{1}(x)$ として $A(x)$ を仮定しても大過ない場合がある。

さて,このような場合においてては，曲げに抵抗する部 材の体積 $V$ を一定にしなければならないから，

$$
V=\int_{0}^{l} A_{1}(x) d x
$$

が拘束条件式である。 $\alpha(x)$ は仮定值 $A(x)$ を採用する ので, 式 (4.2) の未知関数は $I(x)$ のみとなる。

末知断面 $A_{1}(x)$ を与える末知関数を $y(x)$ として， パラメーター $\beta, \gamma, \zeta, \theta$ を,

$$
\left.\begin{array}{l}
A_{1}(x)=\gamma y^{\theta}(x) \\
I(x)=\beta y^{5}(x)
\end{array}\right\}
$$

と定義する。ここに, $y(x)$ はかならずしも直径や厚さ などのように具体的なものでなく, $A_{1}(x)$ と $I(x)$ と の関係を与えるものであればよい。

式 (4.4) を式 (4.2), 式 (4.3) へ代入して, 拘束条 件式 (4.3) のもとに $\Gamma$ を最小にすることは, 変分法に よって解決される。結果を示すとつぎのようになる。

$$
\begin{aligned}
& y(x)=C \cdot \alpha(x)^{1 /(\zeta+\theta)} \\
& \left.C=\left(\frac{V}{r \int_{0}^{l}\{\alpha(x)\}^{\theta /(\theta+\zeta)} d x}\right)^{1 / \theta}\right\} .
\end{aligned}
$$

仮定した $A(x)$ と式 (4.5) より得られる值とに差を 生じた場合には，改めて計算を繰り返せばよい。

\section{5. 全断面が曲げに抵抗する無限自由度系}

ライニングのような付加的断面が存在せず, 全断面が 曲げに抵抗する場合でも，前節に述べたように仮定した 断面 $A(x)$ と式 (4.5) における $y(x)$ より得る断面 
$A_{1}(x)$ とが一致するまで繰り返し計算をすれば，解決 される。しかし，特別な断面形状の場合には，理論解が 得られる。これ恃著者の試算によって得られたもので， 理論的な解析法によって導き得たものではないので, 結 果のみを簡単に示す。

\section{（1）角柱，あるいは円柱}

角柱の 1 辺, あるいは, 円柱の直径を $y(x)$ として, $A(x)$ と $I(x)$ を表わすと，一般的には

$$
\left.\begin{array}{l}
A(x)=\gamma y^{2}(x) \\
I(x)=\beta y^{4}(x)
\end{array}\right\}
$$

となる。 $x$ は埋込端（基礎部分）を原点にして自由端へ 向う方向を正とする。高さを $l$, 総体積を $V$ とする。

まず， $y(x)$ をつぎのように仮定する。

$$
y(x)=\sqrt{\frac{5 V}{2 r l}}\left(1-\frac{x}{l}\right)^{3 / 4}
$$

式 (5.2) と式 (5.1) を式 (4.2) 一代入して, $\alpha(z)$ を求めると，

$$
\alpha(z)=\frac{8}{63} V l^{-5 / 2}(l-z)^{9 / 2}
$$

を得る。式 (5.1) と式 (4.4) の対応上り, $\zeta=4, \theta=2$ を得るので, これらの関係を式 (4.5) 一代入して $C$ を 求めると,つぎのようになって, 最初に仮定した $y(x)$ を得る。

$$
\begin{aligned}
C= & {\left[\frac{V}{\gamma \int_{0}^{l}\left(\frac{8 V}{63}\right)^{1 / 3} l^{-5 / 6}(l-x)^{3 / 2} d x}\right]^{1 / 2} } \\
= & \sqrt{\frac{5}{2}} l^{-5 / 4} \sqrt{\frac{V}{r}}\left(\frac{63 l^{5 / 2}}{8 V}\right)^{1 / 6} \\
& \therefore y(x)=\sqrt{\frac{V}{2 \gamma l}}\left(1-\frac{x}{l}\right)^{3 / 4}
\end{aligned}
$$

最後に, $y(x)$ が総体積に関する条件式 (4.3) を満足 することは，

$$
V=\int_{0}^{l} A(x) d x=\frac{5 V}{2 l} \int_{0}^{l}\left(1-\frac{x}{l}\right)^{3 / 2} d x=V
$$

として示される。

ゆえに, 式 (5.2) に仮定した $y(x)$ は最適断面変化 を与えることがわかる。

\section{(2) 中空断面}

肉厚一定の中空断面で, 内径のみが変化する断面形状 をもつ, 煙突のような構造物を仮定する。 $x$ 座標は埋込 み端を原点として, 上方を正とする。高さを $l$, 総体積 を $V$ とする。内径を $y(x)$ とすれば, $I(x)$ と $A(x)$ の一般式は,

$$
\left.\begin{array}{l}
I(x)=\beta y^{3} \\
A(x)=\gamma y
\end{array}\right\}
$$

となる、最適断面を表わす $y(x)$ を

$$
y(x)=2 V(l-x) / r l^{2} .
$$

と仮定し，前節と同様にして $\alpha(z)$ を求めると，

$$
\alpha(z)=\frac{2 V}{l^{2}} \int_{z}^{l}(l-z)(z-x)^{2} d x=\frac{V}{6 l^{2}}(l-z)^{4}
$$

を得る。 $\zeta=3, \theta=1$ であるから，式 (4.5)より $y(x)$ を求めると，

$$
\left.r \int_{0}^{l}\{\alpha(z)\}^{1 / 4} d z=\frac{r}{2} \frac{l^{2}}{6 l^{2}}\right)^{1 / 4}
$$

となり,

$$
y(x)=2 V(l-x) / r l^{2}
$$

を得る。総体積が $V$ になることは明らかであるから， すべての条件が満足されていることがわかる。

この結果より, 煙突のような中空断面の構造では, 直 径が直線状に変化している場合に $\Gamma$ が最も小さくなる といら結論を得る。しかし，実際の問題として頂部の直 径が 0 ということはあり得ないので，直接役立つ結果で はないが，設計上の参考にはなるであろう。

\section{6. 頂部に集中質量をもつ片持ばり}

橋脚のように頂部に大きな集中質量 (上部構造)をも つ片持ばりでも，有限自由度系とみなして質量分布が既 知なものとするならば，すでに導いた式 (3.2)によって 断面変化を決定し得る。しかし，質量分布も未知である とするならば，繰り返し計算を行なわなければならな い。この場合の収れん性は非常にすぐれているが，ごく 簡単な計算例を用いて, 収れん性を検討し, あわせて, 実際の断面がどのようになるかを求めて図示した。

図一4 に示すように，曲げ剛さ無限大の集中質量が頂 部に存在するような片持ばりを対象にする。はりの部分 は $N$ 等分して, それぞれの区間で断面が階段状に変化 しているものとする。各区間の質量は断面の関数であっ て，分割点に集中しているものとする。

頂部の質量とはりの質量の比重を等しく $っ$ として,

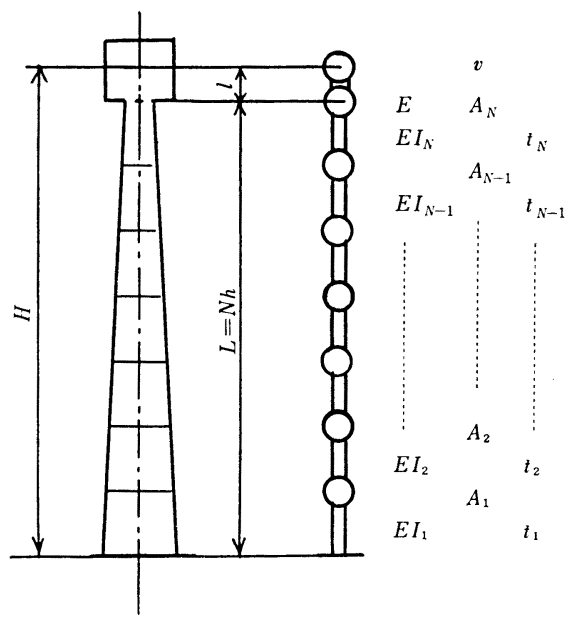

図-4 
それぞれの換算体積を $v, V$ とする。はりの部分の全断 面が曲げに抵抗するものとして, 曲げによる横振動のみ 考える。はりの高さを $L=N h$ として，はりの先端か ら頂部質量の重心までを $l$ とする。

はりの部分の載荷点載荷方向たわみ $f_{k k}$ と, 集中質 量の重心における載荷方向たわみ $f_{e}$ は, つぎのように なる。

$$
\begin{aligned}
& f_{k k}=\int_{0}^{k h} \frac{(k h-x)^{2}}{E I(x)} d x \\
& =\sum_{j=1}^{k} \frac{h^{3}}{E I_{j}}\left[k^{2}-\left\{j^{2}-(j-1)^{2}\right\} k\right. \\
& \left.+\frac{1}{3}\left\{j^{3}-(j-1)^{3}\right\}\right] \\
& f_{l}=\int_{0}^{L} \frac{(L+l-x)^{2}}{E I(x)} d x=\frac{1}{E}\left(\frac{L}{N}\right)^{3} \sum_{j=1}^{N} \frac{\alpha_{2}(j)}{I_{j}} \\
& \alpha_{1}(j)=\sum_{i=j}^{N} A_{i}\left(i^{2}+i+\frac{1}{3}\right) \\
& -j \sum_{i=j}^{N} A_{i}(2 i+1)+j^{2} \sum_{i=j}^{N} A_{i} \\
& \alpha_{2}(j)=\frac{N v}{L}\left\{j^{2}-j\left(2 N+1+\frac{2 N l}{L}\right)\right. \\
& \left.\left.+\left(N+1+\frac{N l}{L}\right)\left(1+\frac{l}{L}\right) N+\frac{1}{3}\right\}\right) \\
& \therefore \quad \Gamma=\frac{\rho}{E}\left(\frac{N}{L}\right)^{4} \sum_{i=1}^{N}\left\{\alpha_{1}(i)+\alpha_{2}(i)\right\} \frac{1}{I_{i}}
\end{aligned}
$$

ここに, $A_{i}, I_{i}$ は各点の断面積と断面 2 次モーメント である。それぞれ

$$
\left.\begin{array}{l}
I_{i}=\beta \cdot t_{i}{ }^{6} \\
A_{i}=r t_{i}{ }^{\theta}
\end{array}\right\}
$$

と仮定し $V=h \stackrel{N}{\sum} A_{i}$ という条件のもとに, $\Gamma$ を最小 にするような $t_{i}$ を求めることになる。

しかるに， $\alpha_{1}(j)$ は未知数であって理論的には解き得 ないので, 仮定断面 $A_{i}{ }^{\prime}$ によって $\alpha_{1}(j)$ を定めてから, $\Gamma$ を最小にするべく Lagrange の未定係数法を用いる。

$$
t_{i}=\left(\frac{N V}{r L}\right)^{1 / 5} \frac{\left\{\alpha_{1}(i)+\alpha_{2}(i)\right\}^{1 /(\zeta+\theta)}}{\left[\sum_{1}^{N} \alpha_{1}(j)+\alpha_{2}(j)^{\theta /(\theta / \zeta)}\right]^{1 / \theta}}
$$

逐次計算は, 仮定断面 $A^{\prime}{ }_{i}$ より $\alpha_{1}(i), \alpha_{2}(i)$ を求め て, 式 (6.4)より $t_{i}$ を定め, これを式 (6.3) に代入 して, $A_{i}$ を求める。求めた $A_{i}$ が仮定值 $A^{\prime}{ }_{i}$ と許容值 以上の誤差を含むならば， $A_{i}$ ，を仮定值として計算を繰 り返す。

図一5 は分割数 $N$ の変化によって断面がどのように 変化するかを考察するために, $N=10,20,50$ について 数值計算を行なった結果を示す。この例では, 断面を角 柱として, $L=10, l=1, V=10, v=1, \beta=0.5, \zeta=4$,

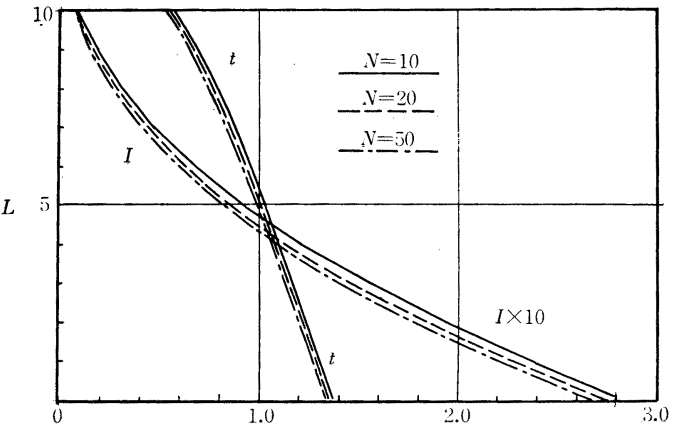

図-5

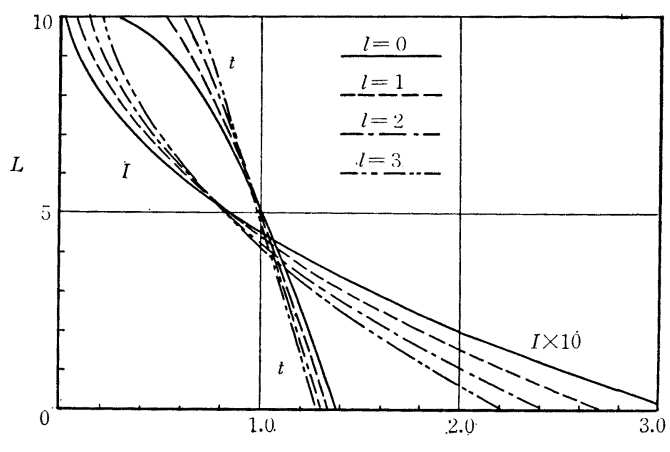

図-6

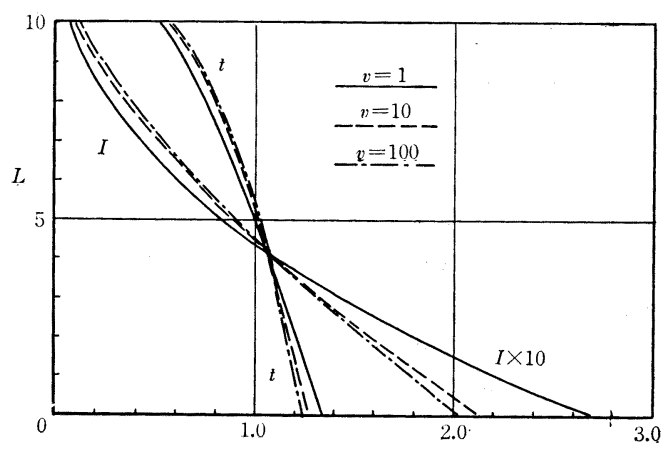

図一7

$\gamma=1, \theta=2$ とした。収れん誤差を $\varepsilon=\Sigma\left|A^{\prime}{ }_{i}-A\right| / \Sigma A_{i}$ $\leqq 5 \times 10^{-6}$ としたが，すべての場合について，5回の繰 り返しで収れんしている。 $t_{i}, I_{i}$ が $N$ の増加とともに 減少しているのは, 各区閒を階段変化としたためであ る。

図一6 は, $N=40, \beta=1 / 12, \zeta=4, \gamma=1, \theta=2, L=10$, $V=10, v=1$ として, 集中質量の重心 $l$ のを $l=0$, $1,2,3$ と変化させた断面変化を示す。

図一7 は, 図一6 の条件で $l=1$ とし, $v$ を $v=1$, 10,100 と極端に変化させた場合のものである。

これらの計算例は簡単なものであって, 実際の構造物 に適したものではないが， $\Gamma$ を最小にする断面変化の特 性を探るために，モデル化して極端な条件を与えて計算 
したものである。したがって，図一5〜図一7には単位 を示していない。 $t$ あるいは，I の相対的変化がどのよ うになるかを図示したものであるから， $L, t, I$ それ ぞれの単位をどのように解釈してもよい。その結果 $V$, $v, \Gamma$ の単位が変化するのみである。図一5 は $N$ の増加 による変化, 图一6 は， $l / L$ の変化による断面形状の変 化, 図一7 は $v / V$ の比率の変化による断面形状の変化 を示しているものである。

\section{7. 動的応答と $\Gamma$ との関係}

固有周期の自乗和の最小化といらことは，物理的な意 義はないように思われるので，本文はあくまでも，近似 的に基本振動周期 $T_{1}$ を最小化する断面変化法と解釈さ れるべきものであろう。しかるに，動的応答と $\Gamma$ を関 連させようとするならば,つぎのように特定な構造系に 特定な外力が作用した場合の「応答の平均運動エネルギ 一 W」と解釈される。

有限 $N$ 自由度系の構造物を対象にする。

$[m]$ : 各点の換算集中質量 $m_{i}$ を対角要素とする対角 行列。

$[S]$ : Stiffness matrix で, 固有值行列 [ג], 固有心゙ クトル $[\varphi]$ をも $,[\varphi]^{T}[S][\varphi]=[\lambda],[\varphi]^{T}$ $[m][\varphi]=E$ を満足する。

$[C]$ : 減衰力を現わし, $[\varphi]^{T}[C][\varphi]=2[\zeta \sqrt{\lambda}]$ を満 足する。ここに, $[\zeta \sqrt{\lambda}]$ は対角行列で， $\zeta_{j}$ は 各モードの減衰定数を意味する。

本節においてのみ $i$ を虚数単位として, 外力を $[m]$ $[\varphi]\left\{a \zeta_{k} e^{i} \sqrt{\lambda_{k}} t\right\}$ という外力と仮定し， $\{y\}=[\varphi]\{q(t)\}$ とすれば, この系の振動方程式は,

$$
[m]\{\ddot{y}\}+[C]\{\dot{y}\}+[S]\{y\}=[m][\varphi]\left\{a \zeta_{k} e^{i \sqrt{\lambda_{k}} t}\right\}
$$$$
\ddot{q}_{k}(t)+2 \zeta_{k} \sqrt{\lambda_{k}} \dot{q}_{k}(t)+\lambda_{k} q_{k}(t)=a \zeta_{k} e^{i \sqrt{\lambda_{k}} t}
$$

となる。全体の運動エネルギー平均 $W$ は，

$$
W=\frac{1}{2} \sum_{k=1}^{N} m_{k}\left|\dot{y}_{k}\right|^{2}=\frac{a^{2}}{8} \sum_{k=1}^{N} \frac{1}{\lambda_{k}}=\frac{a^{2}}{32 \pi^{2}} \Gamma
$$

となることは明らかである。

$[C]$ に対する仮定は, 構造物の減衰特性が解明され ないと, 可否を論じられない。外力の分布に関する上記 のような仮定は, 最も危険な周期成分の外力がほぼ等し いような振幅をもち，かつ，各モードに比例した振幅分 布で作用した場合といえよう。

したがって， $\Gamma$ を最小化するといらことは，あくまで も近似的な意味において、「それぞれの固有周期に近い 周期成分のパワースペクトルをほぼ等しい大きさで含 むようなランダムな外力が作用した場合の構造物の応答 の運動エネルギーを最小化する設計法」とみなし得よ う。

構造物の基本周期を小さくすることは，上記のような 観点からは応答の運動エネルギーを小さくすることに相 当し, いずれにせよ，剛な構造物を設計することに相当 する。

\section{8.むすび}

構造物の非常に特殊な設計法を, 偶然, 変分法によっ て解き得たので報告した。実用上の問題について，ある いは，物理的な意義について，さらにいろいろな検討を 加えるべきであろう。著者の非力によって，このような 結果しか得られていないが，このような問題に関心を持 たれている方から，有意義なご討議やご指導をいただけ るならば，幸甚に存ずる次第である。この研究におい て, 終始適切なご指導を賜った名古屋大学の成岡教授に は，心から深甚な感謝の意を表したい。

\section{考文献}

1）中川建治：はりの固有值の逆数和に関する二, 三の考察， 土木学会論文集第 150 号 (昭 43.2) pp. 1 7.

(1968. 11.24. 受付) 